\title{
Climate and host plant characteristics effects on lepidopteran caterpillar abundance on Miconia ferruginata DC. and Miconia pohliana Cogn (Melastomataceae)
}

\author{
Scherrer, S. ${ }^{\mathrm{a} *}$, Diniz, IR. ${ }^{\mathrm{b} *}$ and Morais, HC. ${ }^{\mathrm{c} *}$ \\ aPrograma de Pós Graduação em Ecologia, Instituto de Ciências Biológicas, \\ Universidade de Brasília - UnB, Brasília, DF, Brazil

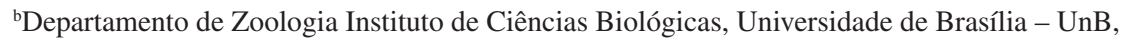 \\ CEP 70910-900, Brasília, DF, Brazil \\ 'Departamento de Ecologia, Instituto de Ciências Biológicas, Universidade de Brasília - UnB, \\ CEP 70910-900, Brasília, DF, Brasil \\ *e-mail: sscherrer@uol.com.br,irdiniz@unb.br, morais@unb.br
}

Received May 2, 2008 - Accepted August 27, 2008 - Distributed February 28, 2010

(With 2 figures)

\begin{abstract}
Folivore cerrado caterpillars are found on their host species in low frequencies, which vary between plants and throughout the year. We analysed the effects of climatic variation and of the characteristics of two host species (Miconia, Melastomataceae) on caterpillar abundance. The work was carried out in a cerrado sensu stricto area in Brasília, Federal District, Brazil, from May 1998 to September 1999. One hundred plants of each species were inspected monthly. All caterpillars found were collected and raised in the laboratory with Miconia leaves as food sources. Climatic data for the study area and plant characteristics such as local density, spatial distribution, foliar phenology, leaf pilosity and nutritional content were used to test the effects on caterpillar abundance. Less than $10 \%$ of the plants had larvae. Caterpillars were more frequent and abundant in M. pohliana, which was also present at higher densities than M. ferruginata. Low caterpillar frequency in host plants and an abundance peak during the dry season are consistent patterns for different cerrado Lepidoptera larvae. This abundance peak, however, is not coincident with higher leaf production in host species. We suggest that $M$. pohliana's higher local density and better leaf digestibility can account for the higher abundance of caterpillars in this species.
\end{abstract}

Keywords: cerrado, foliar nutritional content, host plant, leaf phenology, leaf pilosity

\section{Efeitos do clima e das características das plantas hospedeiras na abundância de lagartas de Lepidoptera em Miconia ferruginata e Miconia pohliana}

\begin{abstract}
Resumo
No cerrado, as lagartas de Lepidoptera, folívoras externas, são encontradas em baixas frequências e variam entre plantas e ao longo do ano. Este trabalho teve como objetivo analisar os efeitos das variações climáticas e das características das plantas (Miconia, Melastomataceae) na abundância das lagartas. O estudo foi feito no cerrado sensu stricto, Brasília, DF, de maio de 1998 a setembro de 1999. Mensalmente, 100 plantas de cada espécie foram vistoriadas. Todas as lagartas foram coletadas e criadas. Foram correlacionados com os resultados obtidos da abundância de lagartas, os dados climáticos e as seguintes características das plantas: densidade local, distribuição espacial, fenologia, pilosidade e conteúdo nutricional foliar. Menos de $10 \%$ das plantas tinham lagartas. As lagartas foram mais frequentes e abundantes em M. pohliana que também foi a espécie de planta com maior densidade na área. A frequência baixa de lagartas em plantas do cerrado é um padrão bastante consistente, assim como o pico de abundância desses imaturos na estação seca. Entretanto, esse pico de abundância não coincide com a produção de folhas em nenhuma das espécies de plantas. A maior densidade local e digestibilidade das folhas de M. pohliana são os fatores que mais explicam a abundância de lagartas nessa espécie.
\end{abstract}

Palavras-chave: cerrado, conteúdo nutricional foliar, fenologia foliar, pilosidade foliar, planta hospedeira. 


\section{Introduction}

Herbivorous insect abundance and richness are influenced by several factors such as climate, presence of parasitoids and/or predators, and a multitude of host plant characteristics such as size, density, spatial distribution, phenology, nutritional content, and chemical composition (Lawton, 1983; Basset, 1991; Stamp and Casey, 1993; Bernays and Chapman, 1994; Kursar and Coley, 2003; Stiling and Moon, 2005). Pilose leaves, for example, are less likely to be attacked by herbivorous insects (Ribeiro et al., 1994; Paleari and Santos, 1998). Some of these relationships are not always straightforward, however. A study on six Melastomataceae species, including Miconia ferruginata DC., in a Cerrado in Lagoa Santa (Minas Gerais, Brazil) found no relationship between insect abundance and tannin concentration in leaves (Ribeiro et al., 1999).

In the markedly seasonal cerrados of central Brazil, insect abundance fluctuates throughout the year. For most orders, peak abundance occurs between October and November (after the first rains). The first half of the dry season (April-June), however, is also favourable for some insects, which become abundant during this period (Pinheiro et al., 2002). This is the case of Lepidoptera caterpillars, which show an abundance peak between May and June (Morais et al., 1999).

Cerrado folivore caterpillars, however, are present in host plants at low frequencies throughout the year (Price et al., 1995), and such frequencies vary according to each host species (Diniz et al., 1999; Morais and Diniz, 2004). The goals of the present paper are to analyse the effects of climatic variation and host-plant characteristics on caterpillar abundance in two species of Miconia (Melastomataceae) in a cerrado in central Brazil.

\section{Material and Methods}

The study was carried at the University of Brasília's Farm (Fazenda Água Limpa, FAL, Brasília, Federal District, Brazil; $15^{\circ} 57^{\prime} \mathrm{S}$ and $47^{\circ} 57^{\prime} \mathrm{W}$ ) in a cerrado sensu stricto area (Goodland, 1971), from May 1998 to September 1999.

The region has a typical cerrado climate, with a marked seasonality and a dry season from May to September (Espinoza et al., 1982), with mean annual temperature and precipitation of $22{ }^{\circ} \mathrm{C}$ and $1,431 \mathrm{~mm}$, respectively. Study area characteristics such as soil, climate, and vegetation are described in Felfili et al. (1993, 1994). A precise description of the vegetation at FAL can be found in Ratter (1991).

The Melastomataceae is one of the most representative families in cerrado sensu lato, with 74 genera. Miconia is a large genus, represented by 25 species in the Federal District (Cavalcanti and Ramos, 2001). We selected two species from this genus, Miconia ferruginata DC. and M. pohliana Cogn for the present study. These are shrubs or small trees with star-shaped hair on both leaf sides, frequently found in cerrado sensu stricto near
Brasília. They are evergreen sclerophyls that are known to accumulate aluminum (Haridasan, 1982; 1988).

In a $5 \mathrm{~km}^{2}$ area subdivided into 17 smaller parcels, we carefully searched 200 plants monthly (100 for each species) for Lepidoptera caterpillars. Presence, characteristics, and location of caterpillars were recorded for each plant. Caterpillar specimens were brought to the laboratory and raised without temperature or humidity control in individual plastic jars, with host leaves as food source. Leaves were kept turgid with wet cotton wrapped around the petiole, regularly changed every two days. We recorded date of pupae collection, adult emergence, and presence of parasitoids. Adults were dry mount, identified by Vitor Osmar Becker, and deposited at the Entomology collection of the Department of Zoology at the University of Brasília.

We recorded the estimated percentage of new leaves (foliar phenology) and plant height for each plant examined. We ranked plants in to five classes, according to the percentage of new leaves: 1) $0 \%$; 2) 1 to $25 \%$; 3) 26 to $50 \%$; 4) 51 to $75 \%$ e 5) 76 to $100 \%$ of new leaves. Tree height was measured with a $2 \mathrm{~m}$ collapsible wood ruler.

We determined density and spatial distribution of each species' individuals using a $1 \mathrm{~km}$ long transect with 30 randomly chosen $100 \mathrm{~m}^{2}$ sites. Each site had a randomly chosen perpendicular distance (left or right) from the main transect. We counted all individuals from both species in each site. We used three methods to confidently detect spatial distribution patterns of $M$. ferruginata and M. pholiana (Meirelles and Luiz, 1995): Morisita and Poisson indexes and the ratio between observed and expected densities (Brower et al., 1997).

To quantify the hosts' nutritional content, we collected four young and four mature leaves in different locations in the plant from 10 individuals of each species. In the laboratory, we washed each leaf with distilled water, packed them individually in paper bags, and placed them in an oven for 48 hours at $75^{\circ} \mathrm{C}$. The following characters were measured for each sample at the Embrapa-Cerrados laboratory: nitrogen percentage, total protein percentage, and in vitro digestibility. We arcsine transformed each of the above percentages, calculated the average and standard deviation, and compared the results with a $t$ test.

We measured foliar pilosity under a dissection scope by counting the number of hair stems in a $1 \mathrm{~cm}^{2}$ area delimited with a cardboard frame. We measured 10 new and 10 mature leaves from 10 individuals of each species taken from the dry and rainy seasons.

Because the number of plants with caterpillars varies periodically throughout the year, we used a circular distribution (Zar, 1996) do describe and analyse our abundance data. Months were converted to angles with May randomly chosen as month $1\left(30^{\circ}\right)$ and April 1999 as $12\left(360^{\circ}\right)$. We then calculated the average angle (average month) and the angular dispersion (standard deviation) to identify which months had higher frequencies of plants with caterpillars. 
For each month we used maximal and minimal temperatures, average air humidity, and average rainfall for the study period (May 1998 to September 1999) as climatic variables. Data were obtained from IBGE's reserve (RECOR) meteorologic station. We used a multiple regression to evaluate the correlation between caterpillar occurrence in each host species and climatic variables.

\section{Results}

Only $7.1 \%$ of the 3,400 plants checked had caterpillars (Table 1). The species richness was very high $(\mathrm{n}=35)$, but only twelve species representing nine families were identified by their binomial names (Table 2). Caterpillar frequency in $M$. pohliana $(10.2 \%)$ was more than twice times that found in $M$. ferruginata (4\%) $\left(\chi^{2}=49.24 ; \mathrm{p}<0.0001 ; \mathrm{df}=1\right)$. The number of caterpillars was also larger in $M$. pohliana $(74.2 \%$ of the 330 larvae found).

Frequency of hosts with caterpillars varied during the study period in both species (Figure 1). In May (beginning of the dry season) hosts show the largest caterpillar abundance in both species (Table 3), and the distribution of larvae during the dry season is aggregated in both Miconia (Rayleigh's test, $\mathrm{Z}=22.75$ ).

There was no significant difference in the frequency of plants with caterpillars between May and September of two consecutive years for $M$. pohliana $\left(\chi^{2}=6.69\right.$; $\mathrm{p}<0.15 ; \mathrm{df}=4)$ and $M$. ferruginata $\left(\chi^{2}=7.46 ; \mathrm{p}<0.11\right.$; df $=4$ ) (Figure 1).

Miconia pohliana was present at a higher density than $M$. ferruginata $(\mathrm{t}=2.889 ; \mathrm{p}<0.05)$, and both species distribution were considered aggregated by all indexes used (Table 4). Species heights did not differ in our

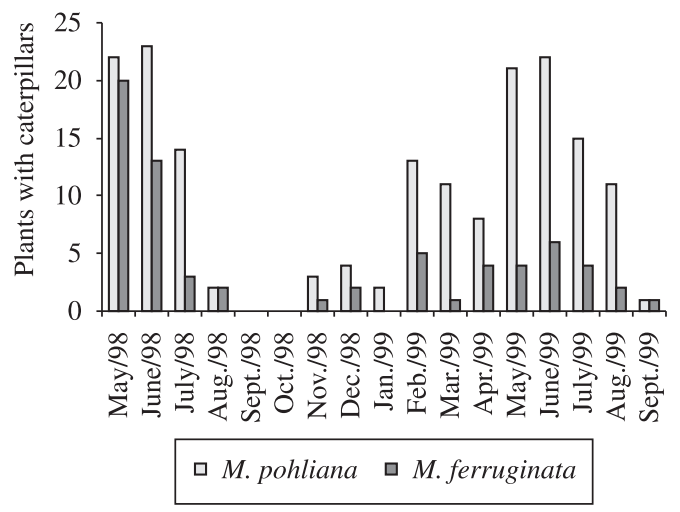

Figure 1. Number of Miconia ferruginata and M. pohliana plants containing caterpillars in the study area (FAL, Brasília, Brazil) from May 1998 to September 1999. A total of 100 plants of each species were examined in each month.

Table 1. Number of plant individuals checked and number of plants containing immature Lepidoptera from May 1998 to September 1999 in a cerrado at FAL (Brasília, Federal District, Brazil).

\begin{tabular}{lccccc}
\hline \multirow{2}{*}{ Species } & \multirow{2}{*}{ Plants checked } & \multicolumn{2}{c}{ Plants with immature } & \multicolumn{2}{c}{ Immature found } \\
\cline { 3 - 6 } & & Caterpillars & Pupae & Caterpillars & Pupae \\
\hline Miconia pohliana & 1,700 & 173 & 6 & 245 & 6 \\
Miconia ferruginata & 1,700 & 68 & 6 & 85 & 6 \\
Total & - & 241 & 12 & 330 & 12 \\
Grand Total & 3,400 & \multicolumn{2}{c}{253} & \multicolumn{3}{c}{342} \\
\hline
\end{tabular}

Table 2. Identified species of Lepidoptera collected and reared on Miconia ferruginata and M. pohliana, from May 1998 to September 1999 in a cerrado at FAL (Brasília, Federal District, Brazil).

\begin{tabular}{|c|c|c|c|}
\hline \multicolumn{2}{|r|}{ Lepidoptera } & \multicolumn{2}{|c|}{ Hostplants } \\
\hline Family & Species & M. pohliana & M. ferruginata \\
\hline Arctiidae & Lophocampa citrina (Sepp., [1852]) & $\mathrm{x}$ & - \\
\hline \multirow[t]{2}{*}{ Elachistidae } & Stenoma hoplítica (Meyrick, 1925) & $\mathrm{x}$ & - \\
\hline & Stenoma ochropa Walsingham, 1913 & - & $\mathrm{x}$ \\
\hline Geometridae & Pleuroprucha asthenaria (Walker, 1861) & - & $\mathrm{x}$ \\
\hline Hesperiidae & Sophista latifasciata (Spitz, 1930) & $\mathrm{x}$ & $\mathrm{x}$ \\
\hline Megalopygidae & Podalia albescens (Schaus, 1900) & $\mathrm{x}$ & $\mathrm{x}$ \\
\hline Noctuiidae & Epidromia conspersata Dognin, 1912 & - & $\mathrm{x}$ \\
\hline Oecophoridae & Inga phaeocrossa (Meyrick, 1912) & - & $\mathrm{x}$ \\
\hline Pyralidae & Quadraforma obliqualis (Hampson, 1906) & $\mathrm{x}$ & $\mathrm{x}$ \\
\hline \multirow[t]{3}{*}{ Riodinidae } & Anteros lectabilis Stichel, 1909 & - & $\mathrm{x}$ \\
\hline & Parcella amarynthina (Felder and Felder, 1865) & $\mathrm{x}$ & - \\
\hline & Theope ca. apheles Bates, 1868 & $\mathrm{x}$ & - \\
\hline
\end{tabular}


Table 3. Circular analysis of caterpillar temporal abundance (number of plants with caterpillars) in Miconia ferruginata and M. pohliana, in a cerrado at FAL (Brasília, Federal District, Brazil).

\begin{tabular}{|c|c|c|c|c|c|c|c|c|c|c|c|c|}
\hline \multirow[t]{2}{*}{ Species } & \multicolumn{9}{|c|}{ Month } & \multirow[t]{2}{*}{$\mathbf{r}$} & \multirow[t]{2}{*}{ Distribution } & \multirow{2}{*}{ Season } \\
\hline & $\mathbf{M}$ & $\mathbf{J} \mathbf{J}$ & $\mathbf{A}$ & $\mathbf{S}$ & $\mathbf{O}$ & $\mathbf{N}$ & D & $\mathbf{J}$ & F $\mathbf{M}$ A & & & \\
\hline Miconia ferruginata & & & & & & & & & & 0.668 & aggregated & Dry \\
\hline Miconia pohliana & & & & & & & & & & 0.530 & aggregated & Dry \\
\hline
\end{tabular}

Caterpillar abundance: largest number of plants with caterpillars (month + standard deviation)

Peak of plants with caterpillars:

Average vector: concentration measure of plants with caterpillars.

Season (dry: May to September; rainy: October to April)

Table 4. Density (in 30 parcels of $100 \mathrm{~m}^{2}$ ) and spatial distribution of Miconia pohliana and Miconia ferruginata in the study area (FAL, Brasília, Brazil).

\begin{tabular}{lcccccc}
\hline \multicolumn{1}{c}{ Species } & Individuals & $\begin{array}{c}\text { largest } \\
\text { N/area }\end{array}$ & $\begin{array}{c}\text { Areas without } \\
\text { individuals }\end{array}$ & $\begin{array}{c}\text { Average } \\
\text { density }\end{array}$ & Id & D/D' \\
\hline M. pohliana & 76 & 8 & 9 & $2.53 \pm 2.5$ & 1.54 & 2.11 \\
M. ferruginata & 31 & 6 & 15 & $1.03 \pm 1.4$ & 1.94 & 1.49 \\
\hline
\end{tabular}

Id = Morisita index; D/D' = ratio between expected and observed densities

Table 5. Dry and rainy season leaf pilosity (hair density in $1 \mathrm{~cm}^{2} ; \mathrm{n}=10$ leaves) in new and mature leaves (average \pm standard deviation) in both Miconia species in the study area (FAL, Brasília, Brazil).

\begin{tabular}{llcccc}
\hline & Season & M. pohliana & M. ferruginata & t & P \\
\hline \multirow{2}{*}{ New leaves } & dry & $331.6 \pm 123.8$ & $147.4 \pm 116.6$ & 4.705 & $<0.001$ \\
& rainy & $250.0 \pm 125.6$ & $203.2 \pm 115.3$ & 0.868 & $>0.30$ \\
\multirow{2}{*}{ Mature leaves } & dry & $2.3 \pm 5.1$ & $3.5 \pm 6.2$ & 0.473 & $>0.70$ \\
& rainy & $12.6 \pm 39.1$ & $1.5 \pm 3.6$ & 0.894 & $>0.40$ \\
\hline
\end{tabular}
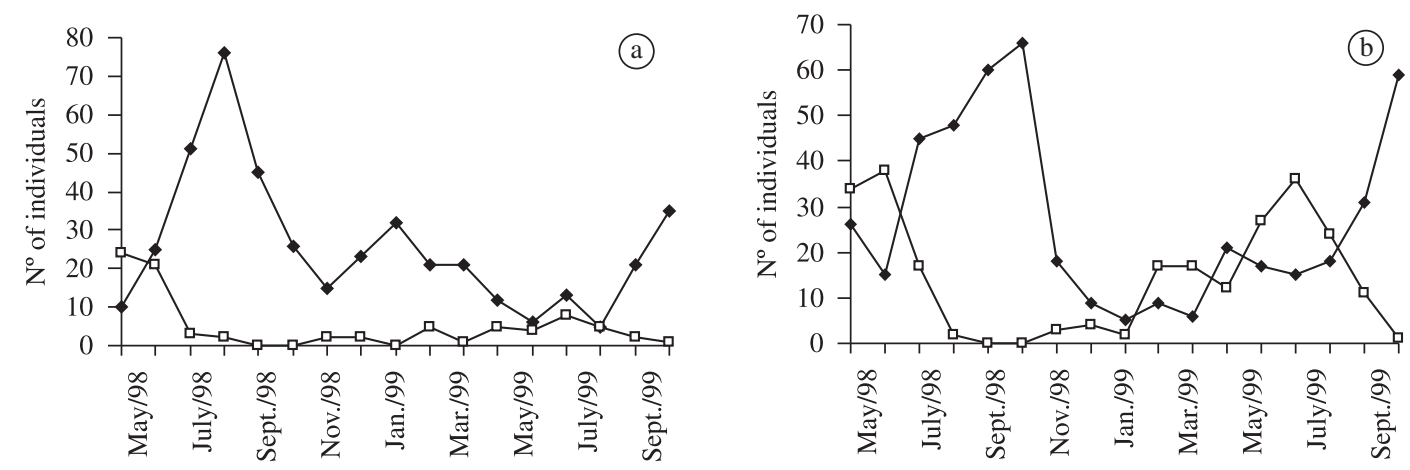

Figure 2. Number of individuals with more than $50 \%$ new leaves and number of caterpillars found in each month from May 1998 to September 1999 a) Miconia ferruginata; b) Miconia pohliana.

study area (M. pohliana $1.22 \mathrm{~m} \pm 0.58$ e $M$. ferruginata $1.25 \mathrm{~m} \pm 0.58)$. Caterpillars were more frequent and abundant on $M$. pohliana.

Both species showed similar foliar phenology. They do not loose leaves synchronically, and leaf production peak occurs from July to September in both species. Results indicate that caterpillar abundance is not corre- lated with the increase in leaf production in either species (Figure 2).

The new leaves of M. pohliana had a higher hair density than $M$. ferruginata in the drier season (Table 5). This difference was not observed in new leaves in the rainy season or in mature leaves of either season. Both species showed higher hair density in new leaves com- 
Table 6. New and mature leaves nutritional quality (average and standard deviation; data arcsin transformed) in Miconia pohliana and M. ferruginata.

\begin{tabular}{|c|c|c|c|c|}
\hline & \multicolumn{2}{|c|}{ Nitrogen } & \multirow[t]{2}{*}{$\mathbf{t}$} & \multirow[t]{2}{*}{$\mathbf{P}$} \\
\hline & Average & Standard deviation & & \\
\hline \multicolumn{5}{|l|}{ New leaves } \\
\hline M. pohliana & 0.084 & 0.0038 & 2.866 & $>0.02$ \\
\hline M. ferruginata & 0.089 & 0.0040 & & \\
\hline \multicolumn{5}{|l|}{ Mature leaves } \\
\hline M. pohliana & 0.078 & 0.0037 & 4.036 & $>0.001$ \\
\hline \multirow[t]{3}{*}{ M. ferruginata } & 0.084 & 0.0029 & & \\
\hline & \multicolumn{2}{|c|}{ Gross protein } & $\mathbf{t}$ & $\mathbf{P}$ \\
\hline & Average & Standard deviation & & \\
\hline \multicolumn{5}{|l|}{ New leaves } \\
\hline M. pohliana & 0.219 & 0.009 & 2.586 & $>0.05$ \\
\hline M. ferruginata & 0.230 & 0.010 & & \\
\hline \multicolumn{5}{|l|}{ Mature leaves } \\
\hline M. pohliana & 0.203 & 0.010 & 3.704 & $>0.01$ \\
\hline \multirow[t]{3}{*}{ M. ferruginata } & 0.218 & 0.008 & & \\
\hline & \multicolumn{2}{|c|}{ Digestibility } & $\mathbf{t}$ & $\mathbf{P}$ \\
\hline & Average & Standard deviation & & \\
\hline \multicolumn{5}{|l|}{ New leaves } \\
\hline M. pohliana & 0.447 & 0.024 & 15.754 & $>0.001$ \\
\hline M. ferruginata & 0.306 & 0.015 & & \\
\hline \multicolumn{5}{|l|}{ Mature leaves } \\
\hline M. pohliana & 0.410 & 0.020 & 9.049 & $>0.001$ \\
\hline M. ferruginata & 0.333 & 0.018 & & \\
\hline
\end{tabular}

pared to mature ones. Even though M. pohliana shows a higher hair density in new leaves, its hairs are shorter and become detached from the leaf more easily than in $M$. ferruginata, which shows longer hairs forming an intricate mesh on the leaf's surface.

New and young M. ferruginata leaves show a significantly higher nitrogen and absolute protein content, but have significantly lower digestibility (Table 6).

Monthly abundance of caterpillars in $M$. ferruginata showed no significant correlation with the climatic variables considered $(\mathrm{F}=2.244 ; \mathrm{p}<0.125)$. For $M$. pohliana, however, climatic variables explain most of the abundance variation $(\mathrm{F}=8.740 ; \mathrm{p}<0.002)$.

\section{Discussion}

We found a low proportion of caterpillars in Miconia ferruginata and M. pohliana. This result has been found recurrently for different plant species in the cerrado (Price et al., 1995; Diniz and Morais, 1997; Diniz et al., 1999), and seems to be a consistent pattern of folivore insects in this biome (Loyola and Fernandes, 1993; Ribeiro et al., 1999).

The higher caterpillar abundance we found in the beginning of the dry season in Miconia species has also been detected in other cerrado species (Morais et al., 1999; Morais and Diniz, 2004). Miconia ferruginata and M. pohliana are evergreen plants that show new, mature, and old leaves throughout the year. A peak in leaf production occurs, however, at the end of the dry season and beginning of the rainy season. This leaf production pattern also occurs in deciduous plants such as Erythroxylum spp. (Erythroxylaceae) and, as in Miconia, the time of higher caterpillar abundance is not coincident with the peak of leaf production (Price et al., 1995).

Temporal variation in caterpillar abundance is expected in a highly seasonal environment such as the Cerrado. Still, why is caterpillar abundance so low during the peak of leaf production in the Miconia species studied? One possible explanation is that leaf production peak (July to September) is also the period of lowest air humidity in the region. Climatic conditions explain most of the caterpillar abundance fluctuation in M. pohliana, and their aggregation in the dry season's first half (May to July), when conditions are less harsh, specially air humidity and minimum temperature. Another possible explanation could be the tendency for higher caterpillar parasitism pressure during the peak of leaf production in cerrados of the Federal District (Morais et al., 1999).

Furthermore, both Miconia species new leaves are heavily covered by hair. Paleari and Santos (1998) showed that the experimental removal of hair from M. albicans new leaves caused them to be attacked more frequently, indicat- 
ing that pilosity may be an efficient barrier for herbivore insects. A similar result was found by Ribeiro et al. (1994) with Tabebuia ochracea (Bignoniaceae). Still, M. ferruginata and M. pohliana share $74 \%$ of the caterpillar species, and of all caterpillar species found in M. pohliana $30 \%$ were in new leaves while in M. ferruginata $57.6 \%$ were using this resource. Hence, new leaves characteristics cannot be used to explain caterpillar low frequency during the period of higher leaf production.

Caterpillars were more abundant in M. pohliana than in M. ferruginata. Both species have an aggregated distribution pattern and similar heights, but $M$. pohliana was two times more abundant in the study area. This characteristic may explain the higher caterpillar abundance in this species, in accordance with the resource concentration hypothesis (Root, 1973). Plants with higher local densities are more easily located in a shorter period of time by females, representing therefore a more attractive and available resource for Lepidoptera.

Therefore, higher leaf digestibility and higher local abundance, as well as other factors not analysed herein, may explain higher caterpillar abundance in M. pohliana. Digestibility is correlated to tissue fiber content and, indirectly, to leaf hardness and sclerophyly. Leaf hardness was the best predictor for variation in herbivore attack in a dry forest in Panama (Coley, 1983), but a similar result was not found for cerrado plants (Marquis et al., 2001).

Variation in precipitation and other climatic characteristics unquestionably influence temporal caterpillar abundance variation in Miconia spp. and other cerrado plant species. Some variables not examined in the present work, such as predator and parasite pressure, secondary chemical compounds concentration, and leaf nutritional quality, which varies with the plant's age and phenophase (Medeiros and Haridasan, 1985; Leitão and Silva, 2004), may also contribute to temporal variation in caterpillar abundance in the cerrado.

Caterpillar frequency in $M$. pohliana $(10.2 \%)$ was more than twice times that found in $M$. ferruginata (4\%). Frequency of hosts with caterpillars varied during the study period in both species but caterpillar abundance is not correlated with the leaf production. Nutritional characteristics (nitrogen and gross protein content) are higher for $M$. ferruginata young and mature leaves, but their digestibility is lower than M. pohliana leaves. Higher digestibility of $M$. pohliana leaves may be an important factor to explain the higher caterpillar abundance found in this host plant.

Acknowledgements - This study was supported by FAPDF, $\mathrm{UnB}$ and CNPq. Field facilities were provided by UnB (FAL) and laboratory facilities by EMBRAPA. Particular thanks are due to Adrian Garda for revising our English.

\section{References}

BASSET, Y., 1991. Leaf production of an overstorey rainforest tree and its effects on the temporal distribution of associated insect herbivores. Oecologia, vol. 88, p. 211-219.
BERNAYS, EA. and CHAPMAN, RF. (Eds.)., 1994. Host plant selection by phytofagous insects. London, England: Chapman \& Hall. 312 p.

BROWER, JE., ZAR, JH. and VON ENDE, CN., 1997. Field and laboratory methods for general ecology. New York: WCB/ McGraw-Hill. 246 p.

CAVALCANTI, TB. and RAMOS, AE., 2001. Flora do Distrito Federal. Brasília, Brasil: Embrapa-Cenargen. 359 p.

COLEY, PD., 1983. Herbivory and defensive characteristics of tree species in lowland tropical forest. Ecological Monography, vol. 53, p. 209-233.

DINIZ, IR. and MORAIS, HC. 1997. Lepidopteran caterpillar fauna of cerrado host plants. Biodiversity and Conservation, vol. 6 , p. $817-836$

DINIZ, IR., MORAIS, HC., BOTELHO, AMF., VENTUROLI, F. and CABRAL, BC., 1999. Lepidoptera caterpillar fauna on lactiferous host plants in the central Brazilian cerrado. Revista Brasileira de Biologia = Brazilian Journal of Biology, vol. 59, p. 1-9.

ESPINOZA, CW., AZEVEDO, LG. and JARRETA, M., 1982. O clima da região dos cerrados em relação à agricultura. Planaltina, Brasil: Embrapa-CPAC. 15 p. Circular Técnica, no. 9 .

FELFILI, JM., SILVA, MC., REZENDE, AV., MACHADO, JWB., WALTER, BMT., SILVA, PEN. and HAY, JD., 1993. Análise comparativa da florística e fitossociologia da vegetação arbórea do cerrado sensu stricto na Chapada Pratinha, DF, Brasil. Acta Botanica Basilica, vol. 6, p. 27-46.

FELFILI, JM., HARIDASAN, M., MENDONÇA, M., FILGUEIRAS, TS., SILVA, MC. and REZENDE, AV., 1994. Projeto Biogeografia do bioma cerrado: vegetação e solos. Cadernos de Geociências, vol. 12, p. 75-166.

GOODLAND, RA., 1971. Physionomic analysis of the "cerrado" vegetation of central. Journal of Ecology, vol. 59, p. 411-419.

HARIDASAN, M., 1982. Aluminum accumulation by some Cerrado native species of central Brazil. Ecology, vol. 59, p. 411-419.

1988. Performance of Miconia albicans (Sw.) Triana, an aluminium accumulating species in acidic and calcareous soils. Community, Soil Science and Plant Nutrition, vol. 19, p. 1091-1103.

KURSAR, TA. and COLEY, PD., 2003. Convergence in defense syndromes of young leaves in tropical rainforests. Biochemical Systematic and Ecology, vol. 31, p. 929-949.

LAWTON, JW., 1983. Plant architeture and the diversity of phytofagous insects. Annual Review of Entomology, vol. 28, p. 23-39.

LEITÃO, AC. and SILVA, OA., 2004. Variação sazonal de macronutrientes em uma espécie arbórea de cerrado, na Reserva Biológica e Estação Experimental de Mogi-Guaçu, estado de São Paulo, Brasil. Rodriguésia, vol. 55, p. 127-136.

LOYOLA Jr., R. and FERNANDES, GW., 1993. Herbivoria em Kielmeyera coriacea (Guttiferae): efeitos da idade da planta, desenvolvimento e aspectos qualitativos de folhas. Revista Brasileira de Biologia = Brazilian Journal of Biology, vol. 53, p. 295-304. 
MARQUIS, RJ., DINIZ, IR. and MORAIS, HC., 2001. Patterns and correlates of interspecific variation in foliar insect herbivory and pathogen attack in Brazilian cerrado. Journal of Tropical Ecology, vol. 17, p. 127-148.

MEDEIROS, RA. and HARIDASAN, M., 1985. Seasonal variations in the foliar concentrations of nutrients in some aluminium accumulating and nonaccumulating species of the cerrado region of central Brazil. Plant Soil, vol. 88, p. 433-436.

MEIRELLES, ML. and LUIZ, JB., 1995. Padrões espaciais de árvores de um cerrado em Brasília, DF. Revista Brasileira de Botânica, vol. 18, p. 183-189.

MORAIS, HC., DINIZ, IR. and SILVA, DMS., 1999. Caterpillar seasonality in a central Brazilian cerrado. Revista de Biologia Tropical, vol. 47, p. 1025-1033.

MORAIS, HC. and DINIZ, IR., 2004. Herbívoros e herbivoria em cerrado: lagartas como exemplo. In AGUIAR, LMS. and CAMARGO AJA. (Eds.). Cerrado: ecologia e caracterização. Planaltina, DF: Embrapa-CPAC. p. 159-175.

PALEARI, LM. and SANTOS, FAM., 1998. Papel do indumento piloso na proteção contra a herbivoria em Miconia albicans (Melastomataceae). Revista Brasileira de Biologia = Brazilian Journal of Biology, vol. 58, p. 151-157.

PINHEIRO, F., DINIZ, IR., COELHO D. and BANDEIRA, MPS., 2002. Seasonal pattern of insect abundance in the Brazilian cerrado. Austral Ecology, vol. 27, p. 132-136.
PRICE, PW., DINIZ, IR., MORAIS, HC. and MARQUES, ESA., 1995. The abundance of insect herbivore species in the tropics: the high local richness of rare species. Biotropica, vol. 27, p. 468-478.

RATTER, JA., 1991. Notas sobre a vegetação da Fazenda Água Limpa (Brasília, DF). Brasília: Editora Universidade de Brasília. 163 p. Textos Universitários, no. 3.

RECOR [on-line]. Available from: http://www.recor.org.br.

RIBEIRO, SP., PIMENTA, HR. and FERNANDES, GW., 1994. Herbivory by chewing and sucking insects on Tabebuia ochracea. Biotropica, vol. 26, p. 302-307.

RIBEIRO, SP., BRAGA, AO., SILVA, CHL. and FERNANDES, GW., 1999. Leaf polyphenols in Brazilian Melastomataceae: esclerophylly, habitats and insect herbivores. Ecotropica, vol. 5, p. $137-146$.

ROOT, RB., 1973. Organization of a plant-arthropod association in simple and diverse habitats: the fauna of collards (Brassica oleracea). Ecology Monography, vol. 43, p. 95-124.

STAMP, NE. and CASEY, TM. (Eds.)., 1993. Caterpillars: ecological and evolutionary constraints on foraging. New York: Chapman and Hall. 587 p

STILING, P. and MOON, DC., 2005. Quality or quantity: the direct and indirect effects of host plants on herbivores and their natural enemies. Oecologia, vol. 142, p. 413-420.

ZAR, JH., 1996. Biostatistical analysis. New Jersey: Prenct-Hall. $662 \mathrm{p}$. 